特集記 事

作物に括ける葉の形態形成扣よび juvenile-adult 相転換に関する分子育種学的研究 吉川貴徳

京都大学大学院農学研究科, 京都市左京区北白川追分町, 干 606-8502

\title{
The molecular-breeding study of leaf molphogenesis and juvenile-adult phase transition in crops
}

Takanori Yoshikawa

Graduate School of Agriculture, Kyoto University, Kyoto 606-8502, Japan

キーワード

イネ，ダイズ，オオムギ，葉，形態形成，変異体，生育相転換

\section{1. はじめに}

植物において葉は主要な光合成器官であり，葉の形態 や角度，葉序は光の利用効率に著しく影響する（Falster and Westoby 2003). 植物の生育に必要な炭水化物の大部 分は光合成に由来するため，光の利用効率を高めること は農作物の多収化に拈いて必要不可欠であり，葉の形態 形成を制御する遺伝的メカニズムに関する多くの研究が 行われてきた。

葉は茎頂分裂組織（SAM）の側方に扣いて発生した 後, 基部一頂部, 向軸一背軸, 中央一側方の 3 軸が形成 され, これらの軸に沿った発生和よび発達により, 複雑 な器官を正確に形成することを可能にしている (Scarpella et al. 2010, Moon and Hake 2011). このらち，基部一頂部 および向軸一背軸の形成に関しては多くの研究が行われ て敃り，これらの軸を規定する種々の分子が同定されて いるのに対し，中央一側方軸の形成に関しては知見が限 られている，そこで，筆者らはイネやオオムギの細葉変 異体の解析を通じて中央一側方軸に沿った発生・発達機 構の解明に取り組んできた（Yoshikawa et al. 2013a, 2014, 2016).

また，高等植物では栄養成長期において juvenile phase から adult phaseへと生育相の移行に伴い，葉を含む様々 な器官が成熟し, 形態が変化する。生育相の転換に関し てはモデル植物であるシロイヌナズナやイネを用いて多 くの研究が行われて扣り, 生育相の進行とともに葉身サ イズ执よ゙縦横比が増大し, 葉の形態は細長くなること

2019 年 10 月 8 日受領 日本育種学会奨励賞受賞 (第 56 号) 2019 年 11 月 6 日 J-STAGE 早期公開

Correspondence: yosshy@kais.kyoto-u.ac.jp
が知られている（Poethig 1990, Kerstetter and Poethig 1998, Itoh et al. 2005). 数多くのイネ品種を扱ら中で, 筆者ら は indica 品種の初生葉はjaponica 品種と比較してより大 きくて成熟した葉を着生することに着目し, japonica 品 種と indica 品種間における生育相転換期の遺伝的制御機 構の解明に取り組んできた。ささらに，生育相転換が未調 査であった我が国の主要作物であるダイズに関しても相 転換により葉の形態が大きく変化することを明らかにし た (Yoshikawa et al. 2013b).

本稿では，これまで筆者らが取り組んできた細葉変異 体扣よび生育相転換の解析について紹介する.

\section{2. 細葉変異体の解析}

イネ品種「台中 65 号」の N-Methyl-N-nitrosourea (MNU) 処理後代より同定された slender leaf 1 （sle1）変異体は葉 身幅が著しく減少した細葉変異体であり, 細葉以外にも 巻葉, 濃緑色, 矮性などの特徵が認められる。葉身幅は 野生型の約 60\% に減少している一方，葉身長に扣いては 約 $80 \%$ の減少にとどまり, 幅方向と長さ方向で減少程度 が異なっていた。細葉表現型の原因を解明するため，葉 身の表皮細胞を可視化して細胞の大きさを定量した結果, 横幅については野生型と同等であった一方, 細胞の長さ は約 $20 \%$ 増加していた。 そこで葉身の幅方向および長さ 方向の細胞数を算出したところ，両方向ともに細胞数が 野生型の $60 \%$ 程度に減少していることが明らかになっ た． 植物では細胞のサイズを増大することで細胞数の減 少を補償する作用が報告されている（Horiguchi and Tsukaya 2011). sle1 では葉身の長さ方向に拈いて明確な 補償効果が認められたものの, 幅方向には補償効果が認 められなかったことから, 補償効果には一定の指向性が 
あると考えられる。したがって， sle1 の細葉表現型は細 胞数の減少と不均一な補償効果の相乗効果に起因すると 考えられた.

葉原基の発生過程を調査するため, sle1 変異体の第 3 葉の発生をイネの葉の発生ステージ P1～P6 のらち P2～ P5 ステージにかけて野生型と比較した結果, 特に P2 P3 にかけての未熟な葉原基に打ける細胞数の増加が野生 型より劣ることが明らかとなった。そこで同ステージの 葉原基を用いて細胞周期の $\mathrm{S}$ 期特異的に発現する histone H4 の in situ hybridization を行った結果，発現シグナルは 野生型より減少し, 細胞分裂活性が低いことが示唆され た。この結果はリアルタイム RT-PCR による histone $H 4$ の発現解析によっても支持された。これらの結果から， $S L E 1$ 遺伝子は細胞分裂活性の維持に主要な役割を担ら ことが推察された。

原因遺伝子を同定するためマップベースクローニング を行った結果，SLE1 は cellulose synthase-like D4 （OsCSLD4）をコードしていることが明らかになった。 Cellulose synthase (CesA) は $\mathrm{N}$ 末端に zinc finger ドメイ ンを有し，8個の膜貫通ドメインと保存性の高い触媒ド メインを中央に有する（Taylor 2008）。このような CesA と類似した構造を有するCesA-like (CSL) 遺伝子は巨大 なファミリーを構築しており, 配列の相同性から 9 サブ ファミリー（CSLA-H,J) に分類されている. CesA 同様
の膜貫通ドメインや触媒ドメインを有することから CSL も何らかの $\beta$ グルカン生合成に関与すると考学られる が， $\mathrm{N}$ 末端の zinc finger ドメインが欠失していることか ら celluloseのような巨大分子ではなく, 主に hemicellulose の合成に関与すると考えられている（Richmond and Somerville 2000). これらサブファミリーは植物種特異的 なものもある一方，CSLDサブファミリ一はこれまで調 ベられた全ての陸上植物に拈いて高く保存されているこ とから，最も古いCSLファミリーのひとつであり，植物 に扣いて普遍的な機能を担うと考兄られている。配列の 相同性から CSLD サブファミリーはさらに 3 クレードに 分けることができ（図 1)，これらの分類は変異体の表現 型の分類と一致する (Hunter et al. 2012). AtCSLD1 や AtCSLD4 が含まれるクレード 1 は花粉特異的に発現し, それらの変異は花粉管の伸長不良を引き起こす（Bernal et al. 2008).AtCSLD3 や OsCSLD1 が含まれるクレード 2 は根に沶いて強く発現し, それらの変異は根毛の発達不 良を引き起こす（Favery et al. 2001, Kim et al. 2007)。これ ら 2 つクレードはいずれも花粉管や根毛などの“tip growth” に関与する一方, クレード 3 に属する CSLD遺 伝子の変異体は植物体全体が縮小することから，他の 2 クレードとは異なる機能を担らことが示唆される（Bernal et al. 2007, Li et al. 2009, Hu et al. 2010, Wu et al. 2010, Hunter et al. 2012, Yoshikawa and Taketa 2017). SLE1 が

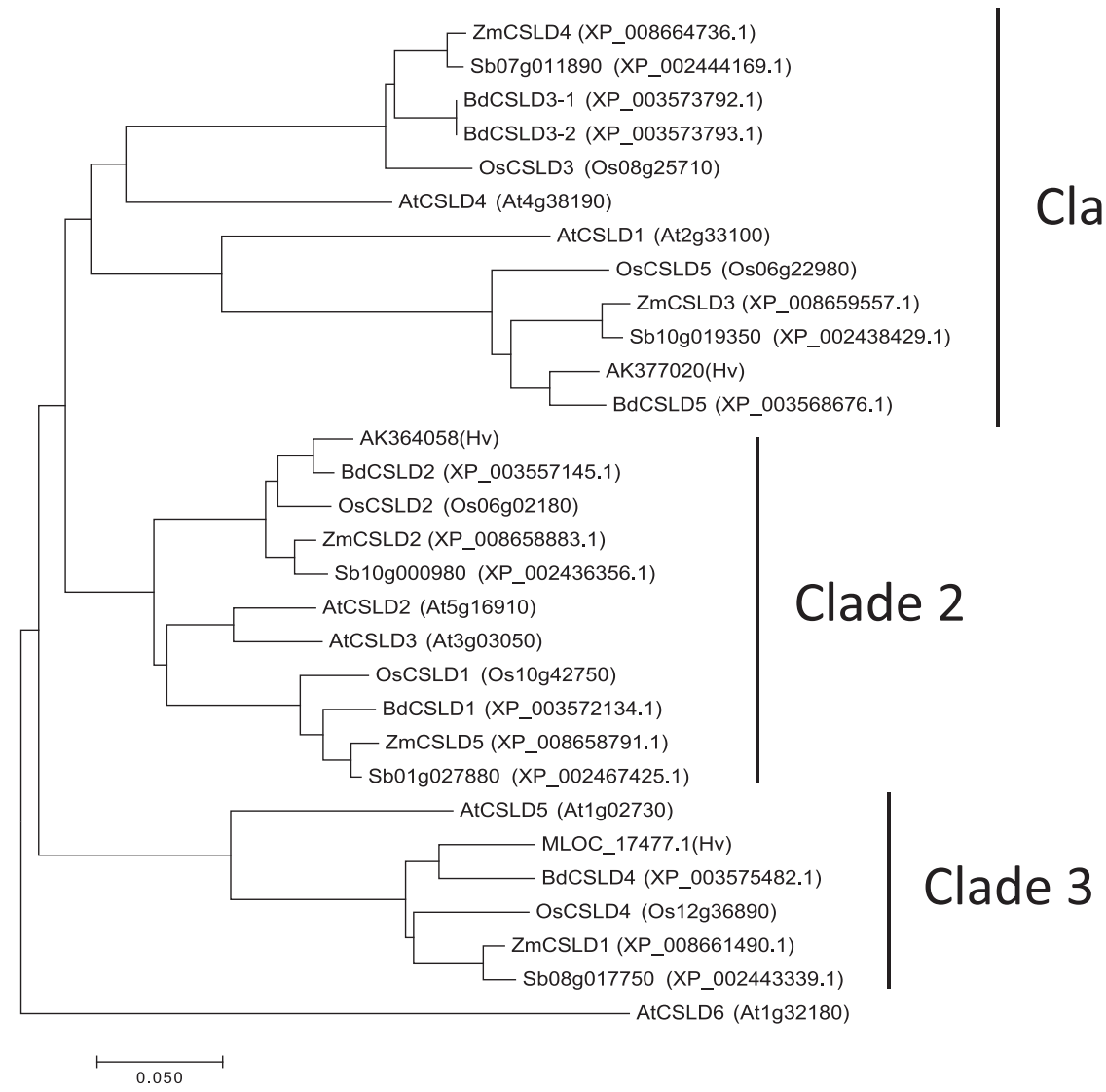

図 1.イネ $(\mathrm{Os})$ ，トウモロコシ $(\mathrm{Zm})$ ，オオムギ $(\mathrm{Hv})$ ，ソルガム $(\mathrm{Sb})$ ，ブラキポディウム（Bd），シロイヌナズナ（At）における $C S L D$ 関連遺伝子の系統樹. 
コードする OSCSLD4 はこのクレード 3 に属しており，そ の発現パターンも未調查であったことから in situ hybridization による発現解析を行った。そ結果，SLE1/ OsCSLD4 は茥頂や根端などの細胞分裂活性の高い組織に 扔いて細胞周期の $\mathrm{M}$ 期特異的に発現して扮り, 組織特異 性は認められなかった。.以上の結果から, SLEI 遺伝子は $\mathrm{M}$ 期特異的に生合成される $\beta$ グルカンの合成に関与して おり，正常な細胞分裂活性の維持に重要な役割を担うと 考えられた。

このよらなイネ研究を通じて得られた知見を活用すべ く，オオムギ細葉変異体 narrow leafed dwarf 1 （nld1）の 解析に取り組んだ. nld 1 b sle1 同様に細葉かつ矮性の表 現型を呈し，葉身長は野生型と大差ない一方，葉身幅が $60 \%$ 程度に減少していた，表皮細胞の幅は野生型と同程 度であったことから，細葉表現型は細胞数の減少による ものと考兄られた，そこで，茎頂の横断切片を用いてP1 〜P4 ステージの葉原基幅を比較したところ, P1 ステージ からすでに葉原基幅が野生型の $80 \%$ 程度に減少してい た. sle1 変異体に括いて明確な葉原基幅の減少が認めら れるのが P3 ステージ以降であることを鑑みると， nld 1 ではsle1 より早い段階から細葉表現型を呈して招り, $N L D 1$ 遺伝子は葉原基の発生に関与すると推察された.

$n l d 1$ の葉は細葉以外飞も葉耳が著しく欠損する特徵を 有していた。葉耳はラミナジョイントの側方末端に形成 される器官であることから，葉耳の欠損や葉身幅の減少 は共通して側方領域の欠失を示唆するものと考光られる. そこで葉縁構造を詳細に比較したところ，nld 1 では葉縁 特異的な鋸歯预よび厚壁組織が欠失していることが明ら かになり，葉縁における横走維管束の形成異常なども認 められた。同様の側方領域の欠失や異常は生殖器官に招 いても認められ，外穎挆よび内頑末端の欠失により内側 の穎果が高頻度で露出していた．以上の結果から，NLD1 は栄養扣よび生殖側生器官の側方領域の発生や発達に主 要な役割を担うと考兄られた。

先行研究により $N L D 1$ は $5 \mathrm{H}$ 染色体上にマッピングさ
れて扮り（Hayashi et al. 1983, Takahashi et al. 1972)，さら なるファインマッピングの結果，NLD1 は WUSCHELRELATED HOMEOBOX3（WOX3）をコードすることが 明らかになった。 $W O X$ 遺伝子は配列の相同性から 3 ク レードに分類され，これらの分類は遺伝子が誕生した時 代と一致すると考兄られる（van der Graaff et al. 2009）. 最も古いと考光られる ancient clade には緑藻やとメッリ ガネゴケの $W O X$ 遺厷子が含まれ，その次に誕生したと 考光られる intermediate clade には顕花植物以外飞も七カ ゲノカズラ植物である Selaginella moellendorffii などが含 まれている，最も新しいWUS clade には顕花植物の久が 含まれ，WUSやWOX3 ファミリーもこのクレードに属す る。様々な变異体を用いた解析から WOX3 は葉の側方領 域の形成に主要な役割を担らことが示唆されて扣り，配 列の相同性から WOX3A, WOX3B の 2 クレードに大別さ れる（図 2）。WOX3A にはトウモロコシの NARROW SHEATH1 (NS1) やNS2, イネの NARROW LEAF2 (NAL2) やNAL3 が含まれて扔り, ns1 ns2 またはnal2 nal3 二重変 異によって葉の側方領域が欠失した細葉表現型を生じる (Scanlon et al. 1996, Nardmann et al. 2004, Cho et al. 2013, Ishiwata et al. 2013)。これら WOX3A 遺伝子は SAM の葉 原基形成予定領域の側方末端において発現することで KNOXをダウンレギュレートし，始原細胞を獲得して葉 の側方方向への成長を促進すると考光ら机ている，才オ ムギに拈いて WOX $3 A$ 遺伝子は $N L D 1$ 一遺伝子しか存在 せず，変異体の表現型はns1 ns2 や nal2 nal3 と類似する ことから同様の機能が保存されているものと推察される. そこで発現パターンを調査するため，NLD1 の in situ hybridization を行った結果，SAM の葉原基形成予定領域 の側方末端に执いて発現が認められ，オオムギに打いて も側方領域の確立に主要な役割を担うことが示唆された。 興味深いことに，NLD1 の発現は葉原基の発生時のみな らず，P4 ステージに到るまで側方末端の数細胞で発現が 維持されていたため，NLD1 は側方領域の発達や葉縁の 維持においても主要な役割を担うと考兄られる。また，

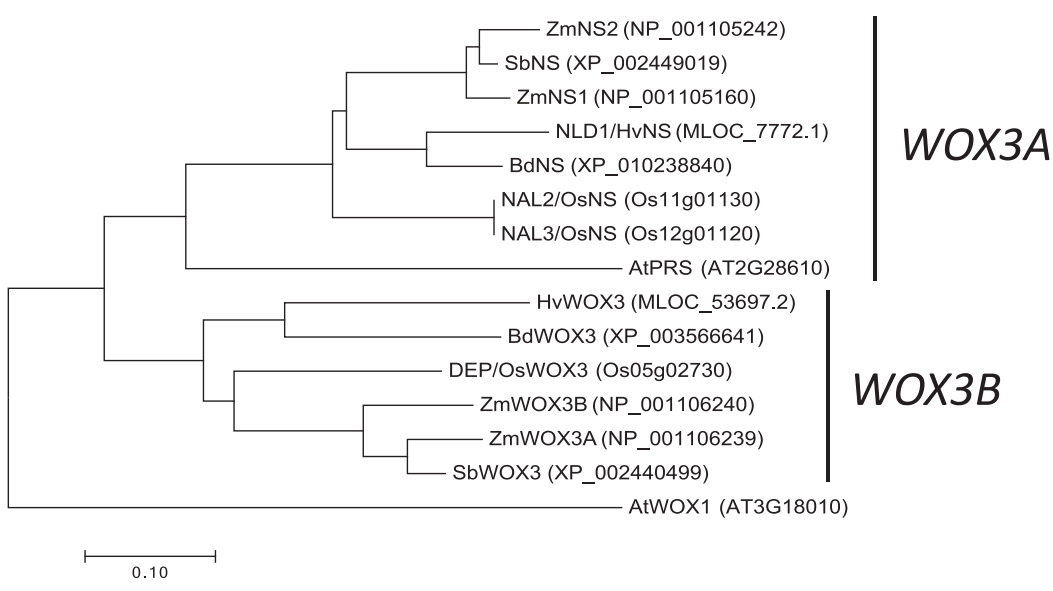

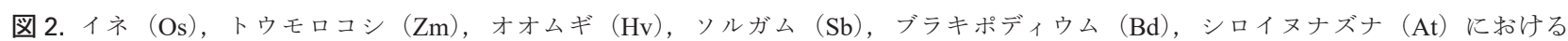
WOX3 関連遺伝子の系統樹. 


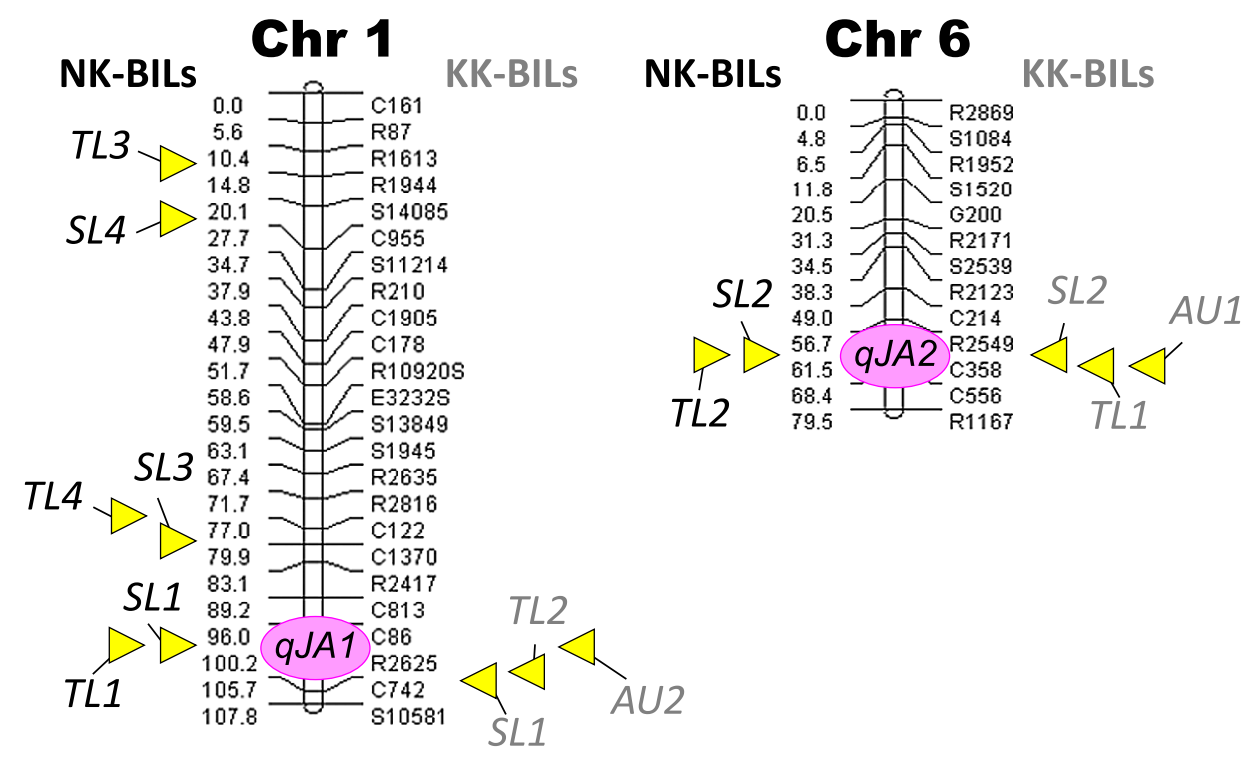

葉縁以外にも P3 葉原基の表皮細胞で部分的に発現シグ ナルが認められ，このよらな細胞はトライコームの発生 する位置と相同的であった。実際に，nld1 変異体ではト ライコームのサイズや密度が野生型より減少傾向にある ため, NLD1 はトライコーム形成にも関与する可能性が ある. Oryza glaberrimaを用いた研究により, イネ WOX3B 遺伝子である DEPILOUS (DEP) は葉や穎におけるトラ イコーム形成に主要な役割を担らことが報告されている ため (Angeles-Shim et al. 2012)，WOX3A が同様の機能を 保存していても驚くべきことではない. 特に，オオムギ では $W O X 3 A$ 遺伝子は NLD1 のみであるため, イネやト ウモロコシとは機能分担が異なっている可能性は十分考 えられる。したがって，オオムギにおけるWOX $3 A$ と $W O X 3 B$ の機能分担については今後さらなる研究が必要で あると考えられる。

\section{3. 生育相転換の解析}

イネ japonica-indica 品種間では発芽後の初期生育が明 確に異なり, indica 品種の第 2 葉はjaponica 品種より顕 著に長く, 葉耳も発達している. japonica 品種の場合, 栄養成長期間に扎いて第 2 葉期までが juvenile phase，第 $3 \sim 5$ 葉期が transition phase, 第 6 葉期以降が adult phase に相当すると考学られて和り, 葉の長さや縦横比, 葉耳 といった形質は juvenile phase から adult phase へ移行する につれて変化することが知られている（Itoh et al. 2005）. したがって, japonica-indica 品種間に括ける初期生育の 差異は juvenile-adult 相転換期の違いに起因する可能性が
あると考兄られる。そこで, japonica 品種（「日本晴」, $\lceil$ 「シヒカリ」, 「台中 65 号」) と indica 品種 (「Kasalath」) を用いて第 2 葉および第 3 葉の葉身長, 中胁形成頻度を 比較したところ, indica 品種はjaponica 品種より明確に 増大していた。 また, japonica 品種では発芽後 13 日頃よ り出葉速度が減少するのに対し, indica 品種では発芽後 10 日頃から減少傾向を示した. これら相転換を制御する 主要な分子として2つの miRNA（miR156, miR172）が知 られており，miR156はjuvenile phase で，miR172 は adult phase で高発現する。 そこで，「日本晴」と「Kasalath」を 用いて miR156 抢よび miR172 の発現量を比較した結果, 「Kasalath」は「日本晴」より早期に miR156および miR172 の発現変化が生じた。これらの結果から，「Kasalath」は japonica 品種よりも形態的および分子的両方面で相転換 が早期化していることが明らかになった。

相転換期の差異を支配する遺伝的要因を解明するため, 「日本晴」メ「Kasalath」BIL 集団（NK-BILs）98 系統拈 よび「コシヒカリ」×「Kasalath」BIL 集団（KK-BILs） 182 系統を供試して相転換形質（第 2 葉葉身長，第 3 葉 葉身長, 第 2 葉葉耳形成頻度）に関する QTL 解析を行っ た. その結果，第 1 染色体の $100 \mathrm{cM}$ 近辺拈よび第 6 染 色体の $60 \mathrm{cM}$ 近辺にNK-BILs 物よび KK-BILs の第 2 葉 および第 3 葉葉身長, 第 2 葉葉耳形成頻度に関する主要 な QTL が共通して検出され（図 3)，いずれも「Kasalath」 型アリルを有する場合に形質值を増大させる効果を示し た.したがって，これらの領域は「Kasalath」の早期相転 換の要因となる主要な QTL であると考学られ，qJA1 お よび $q J A 2$ と命名した. これらの QTLの普遍性を確認す

図 3.「日本晴」×「Kasalath」（NK-BILs） 98 系統扣よび「コシヒカリ」×「Kasalath」（KK-BILs）182 系統に扣いて第 2 葉葉身長 (SL), 第 3 葉葉身長 (TL), 第 2 葉葉耳形成頻度 (AU) に関与する QTLs. 図中の矢頭は各 QTL の LOD 值ピークの位置を示し ており，連鎖地図左側に NK-BILs の，右側に KK-BILs の QTLs を表す. 各 QTLs 後ろの数值は寄与率の高さに準じて番号を付し た. 
るため NIAS Global Rice Core Collection を用いてこれら 2 つの QTLs の遺伝子型を調查したところ，qJA1 $1^{J a p}, q J A 2^{J a p}$ 型, $q J A 1^{\text {Ind }}, q J A 2^{\text {Jap }}$ 型, $q J A 1^{\text {Ind }}, q J A 2^{\text {Ind }}$ 型の 3 タイプが存 在し，興味深いことに $q J A 1^{J a p}, q J A 2^{\text {Ind }}$ 型を見出すことは できなかった（注：Japはjaponicaアリル，Ind はindica アリルを示す)。これら各グループに打ける相転換形質を 調査したところ，第 2 葉葉身長の平均値は $19.9 \mathrm{~mm}$ $\left(q J A 1^{J a p}, q J A 2^{J a p}\right), \quad 59.6 \mathrm{~mm}\left(q J A 1^{I n d}, q J A 2^{J a p}\right), 57 \mathrm{~mm}$ $\left(q J A 1^{I n d}, q J A 2^{I n d}\right)$ となり，第 2 葉葉耳形成頻度は $0 \%$ $\left(q J A 1^{J a p}, q J A 2^{J a p}\right), \quad 65.8 \% \quad\left(q J A 1^{I n d}, q J A 2^{J a p}\right), \quad 79.9 \%$

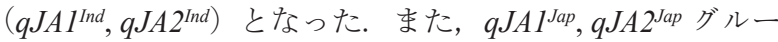
プに含まれる品種は全て japonica 品種であり, qJAI Ind, $q J A 2^{\text {Ind }}$ は全て indica 品種であった. 以上の結果から, こ れら 2 つ QTLs は japonica 品種拈よび indica 品種の相 転換期の分化に関与寸る主要な QTL であることが明らか になったが，これらの QTL がそれぞれの品種群の形成に 打いて選択的に選ばれた理由やその生理的メカニズムに ついてはさらなる研究が必要である。

前述のような生育相転換はイネやトウモロコシといっ た作物に関しては研究が進んでいる一方，わが国の主要 作物であるダイズに関しては未着手である。しかし， $m i R 156$ の過剩発現により分枝数や萊数, 粒重が増加し, 収量を顕著に高められる可能性が示唆されるなど（Sun et al. 2019), ダイズに拈いても生育相転換は育種学的に 重要な形質である。そこで，ダイズの生育相転換に関す る基礎的な知見を得るため，発芽後の植物体に和ける形 態解析を行った，双子葉植物であるダイズは一対の子葉 を展開した後，子葉と垂直に交わるように十字対生で初

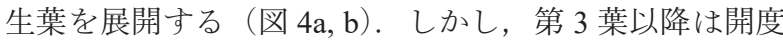
$=180^{\circ}$ で葉を展開させる二列互生へと転換する。また， 子葉沶よび初生葉の形態は単葉であるのに対し, 第 3 葉 以降は 3 枚の小葉から構成される複葉が一般的である. したがって，初生葉から第 3 葉にかけて，葉序は十字対 生から二列互生へ，形態は単葉から複葉へとダイナミッ クに変化し, これらは生育相の進行に伴う変化であると 考光られる。

葉身のサイズは長さ・幅ともに葉位の進行とともに増 大し，第 5 葉で最大值に達する。葉身の縦横比を算出し たところ，第 8 葉に到るまで棌济一貫して増大する傾向 があり，ダイズにおいても葉位の進行とともに葉が細長 くなることが明らかになった，葉身の表面 $5 \mathrm{~mm}$ 四方に 扮ける毛茸の密度を調査したところ，初生葉から第 7 葉 に到るまで一貫して増大し，全ての葉位に扔いて表側よ り裏側の方が高い密度を示した，托葉に関しては，葉位 の進行とともに幅が増大する一方，長さは逆に減少する 傾向を示し, 縦横比は葉位の進行により著しく減少して 第 5 葉で最小值に達した．縦横比に関して葉身と托葉が 異なる挙動を示した点は非常に興味深い.SAM の形態は 完成胚（発芽前）の時点では小さく，平らであったのに 対し，生育とともにサイズが増大し，ドーム状に突出す
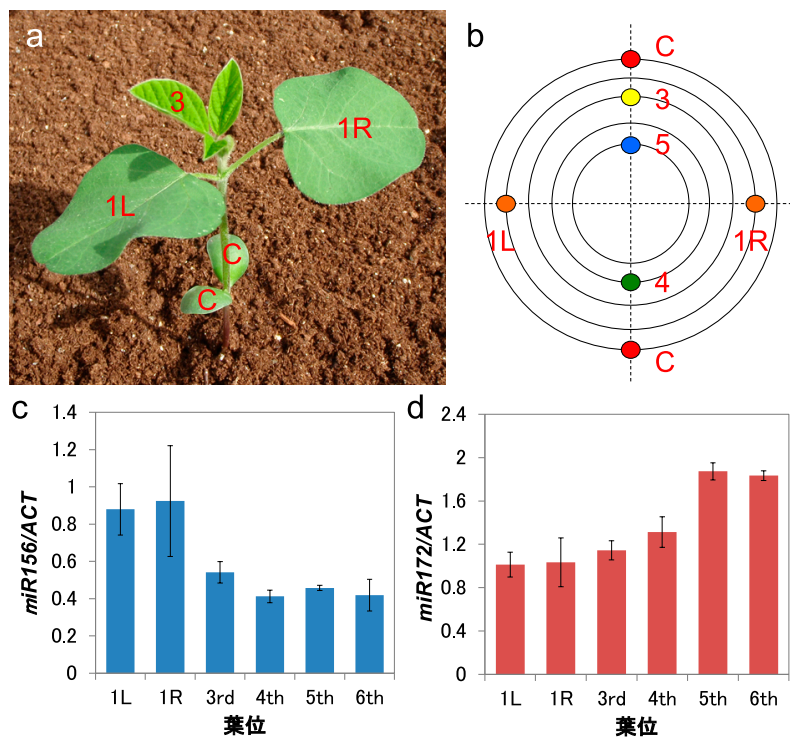

図 4. ダイズ植物体の構造捻よび各葉位における miRNA の発現 变化.

(a) 発芽後 2 週間に打けるダイズ品種「エンレイ」の幼苗

(b) 子葉〜第 5 葉にかけての「エンレイ」の葉序.

(c，d）「エンレイ」の初生葉〜第6 葉葉身に打ける $m i R 156$ (c) 执よび $m i R 172$ (d) の発現変化. $m i R 156$ 打よび $m i R 172$ の発現レベルは $A C T I N(A C T)$ で補正した相対值を示す. 図中の “C”は子葉を，数字は葉位を示す。また，“1L” 拉よび“1R”は第 3 葉を奥側に配置した際の左側拉よび 右側の初生葉を示す.

る形態変化を示した．生育相転換のキーファクターであ る $m i R 156$ 打よび miR172 の発現変化を調査したところ, 初生葉から第 3 葉にかけて miR156 の発現量が顕著に減 少し, $m i R 172$ の発現量は葉位の進行とともに上昇して第 5 葉で最大值に達した（図 $4 \mathrm{c}, \mathrm{d}$ ). 以上の結果から, ダイ ズにおいては初生葉期までが juvenile phase, 第 3 4 葉期 が transition phase，第 5 葉期以降が adult phase に相当す ると考兄られた。

\section{4. おわりに}

本稿で紹介できた細葉変異体はいずれも「細葉」とい ら共通点はあるものの，原因遺伝子を特定すると全て様 式の異なる変異体であった。しかし，側方末端のアイデ ンティティーであり，側方領域の発達を促す WOX $3 A$ は 細胞非自律的な作用をすると考光られ，二次的なシグナ 几因子の存在が示唆される. 興味深いことに nld 1 変異体 では横走維管束の形成に異常が認められ，このような維 管束の配向はオーキシンの極性輸送によって決定される. したがって，WOX3A とオーキシンがぞのように関連づけ られるのかは非常に興味深い。細胞レベルではオーキシ ンは細胞分裂の制御に関わって和り，その制御下に沶い てOSCSLD4 が細胞分裂の進行に関与している. 今後はこ のような分子間の相互作用を解明していくことが植物の 
形態形成機構を紐解く要であると考兄られる。また，遺 伝情報は不変でも葉の形態は生育相転換により大きく変 化し, ダイズでは単葉から複葉へ, 対生から互生へとダ イナミックな変化を伴らことが明らかになった。ささらに 生育相転換はイネ japonica-indica 種の分化とも関連を示 唆して和り,このような分化に関与した遺伝的要因を解 明することで今後の品種改良により広い遺伝資源の有効 活用が期待される.

\section{謝 辞}

本研究の遂行に際し, 東京大学の長戸康郎名誉教授を はじめ育種学研究室の皆様に多大なご指導，ご支援を賜 りましたことを心より感謝申し上げます。また，オオム ギ細葉変異体の解析では武田真教授 (岡山大学) にオオ ムギのことを一から教えていただき，ダイズの生育相転 換では横井修司教授 (大阪府立大学) をはじめ岩手大学 植物育種学研究室の皆様に多大なご協力を賜りましたこ とを社礼申し上げます，最後に，研究室のドアを吒いた 日から今日に至るまで，研究者としてのありようを示し て下さった京都大学の谷坂隆俊名誉教授, 奥本裕教授を はじめ, 日々共に研究に取り組んで下さった京都大学拉 よび吉備国際大学育種学研究室の皆様に心より感謝申し 上げます。

\section{引用文献}

Angeles-Shim, R.B., K. Asano, T. Takashi, J. Shim, T. Kuroha, M. Ayano and M. Ashikari (2012) Rice 5: 28.

Bernal, A.J., J.K. Jensen, J. Harholt, S. Sørensen, I. Moller, C. Blaukopf, B. Johansen, R. de Lotto, M. Pauly, H.V. Scheller et al. (2007) Plant J. 52: 791-802.

Bernal, A.J., C.M. Yoo, M. Mutwil, J.K. Jensen, G. Hou, C. Blaukopf, I. Sørensen, E.B. Blancaflor, H.V. Scheller and W.G.T. Willats (2008) Plant Physiol. 148: 1238-1253.

Cho, S.H., S.C. Yoo, H. Zhang, D. Pandeya, H.J. Koh, J.Y. Hwang, G.T. Kim and N.C. Paek (2013) New Phytol. 198: 1071-1084.

Falster, D.S. and M. Westoby (2003) New Phytol. 158: 509-525.

Favery, B., E. Ryan, J. Foreman, P. Linstead, K. Boundonck, M. Steer, P. Shaw and L. Dolan (2001) Genes Dev. 15: 79-89.

Hayashi, J., I. Moriya and R. Takahashi (1983) Barley Genet. Newslet. 13: 42-44.

Horiguchi, G. and H. Tsukaya (2011) Front. Plant Sci. 2: 1-6.
Hu, J., L. Zhu, D. Zeng, Z. Gao, L. Guo, Y. Fang, G. Zhang, G. Dong, M. Yan, J. Liu et al. (2010) Plant Mol. Biol. 73: 283-292.

Hunter, C.T., D.H. Kirienko, A.W. Sylvester, G.F. Peter, D.R. McCarty and K.E. Koch (2012) Plant Physiol. 158: 708-724.

Ishiwata, A., M. Ozawa, H. Nagasaki, M. Kato, Y. Noda, T. Yamaguchi, M. Nosaka, S. Shimizu-Sato, A. Nagasaki, M. Maekawa et al. (2013) Plant Cell Physiol. 54: 779-792.

Itoh, J., K. Nonomura, K. Ikeda, S. Yamaki, Y. Inukai, H. Yamagishi, H. Kitano and Y. Nagato (2005) Plant Cell Physiol. 46: 23-47.

Kerstetter, R.A. and R.S. Poethig (1998) Annu. Rev. Cell Dev. Biol. 14: 373-398.

Kim, C.M., S.H. Park, B.I. Je, S.H. Park, S.J. Park, H.L. Piao, M.Y. Eun, L. Dolan and C. Han (2007) Plant Physiol. 143: 1220 1230.

Li, M., G. Xiong, R. Li, J. Cui, D. Tang, B. Zhang, M. Pauly, Z. Cheng and Y. Zhou (2009) Plant J. 60: 1055-1069.

Moon, J. and S. Hake (2011) Curr. Opin. Plant Biol. 14: 24-30.

Nardmann, J., J. Ji, W. Werr and M.J. Scanlon (2004) Development 131: $2827-2839$.

Poethig, R.S. (1990) Science 250: 923-930.

Richmond, T.A. and C.R. Somerville (2000) Plant Physiol. 124: $495-$ 498.

Scanlon, M.J., R.G. Schneeberger and M. Freeling (1996) Development 122: 1683-1691.

Scarpella, E., M. Barkoulas and M. Tsiantis (2010) Cold Spring Harb. Perspect. Biol. 2.a001511.

Sun, Z., C. Su, J. Yun, Q. Jiang, L. Wang, Y. Wang, D. Cao, F. Zhao, Q. Zhao, M. Zhang et al. (2019) Plant Biotechnol. J. 17: 50-62.

Takahashi, R., J. Hayashi, T. Konishi and I. Moriya (1972) Ber. Ohara Inst. landw. Biol., Okayama Univ. 15: 147-168.

Taylor, N.G. (2008) New Phytol. 178: 239-252.

van der Graaff, E., T. Laux and S.A. Rensing (2009) Genome Biol. 10: 248.

Wu, C., Y. Fu, G. Hu, H. Si, S. Cheng and W. Liu (2010) Planta 232: 313-324.

Yoshikawa, T., M. Eiguchi, K. Hibara, J. Ito and Y. Nagato (2013a) J. Exp. Bot. 64: 2049-2061.

Yoshikawa, T., S. Ozawa, N. Sentoku, J. Itoh, Y. Nagato and S. Yokoi (2013b) Planta 238: 229-237.

Yoshikawa, T., M. Ito, T. Sumikura, A. Nakayama, T. Nishimura, H. Kitano, I. Yamaguchi, T. Koshiba, K. Hibara, Y. Nagato et al. (2014) Plant J. 78: 927-936.

Yoshikawa, T., S.Y. Tanaka, Y. Masumoto, N. Nobori, H. Ishii, K. Hibara, J. Itoh, T. Tanisaka and S. Taketa (2016) Breed. Sci. 66: 416-424.

Yoshikawa, T. and S. Taketa (2017) Brewing Technology, INTECH press, pp. 3-28. 